\title{
Influence of Drought Stress on Oxidative Damage and Antioxidant Defense Systems in Tolerant and Susceptible Wheat Genotypes
}

\author{
Hojjat Hasheminasab ${ }^{1}$, Mohammad Taghi Assad ${ }^{1}$, Ali Aliakbari ${ }^{1} \&$ Seyyed Rasoul Sahhafi ${ }^{1}$ \\ ${ }^{1}$ Department of Plant Production and Plant Breeding, College of Agriculture, Shiraz University, Shiraz, Iran \\ Correspondence: Hojjat Hasheminasab, Department of Plant Production and Plant Breeding, College of \\ Agriculture, Shiraz University, Shiraz, Iran. Tel: 98-913-994-6843. E-mail: hojathashemi@gmail.com
}

Received: February 6, 2012 Accepted: February 20, 2012 Online Published: June 29, 2012

doi:10.5539/jas.v4n8p20 URL: http://dx.doi.org/10.5539/jas.v4n8p20

\begin{abstract}
Drought is one of the major factors limiting crop production in arid and semi-arid regions. Twenty wheat genotypes with wide range of sensitivity to drought, including 18 varieties of bread wheat (Triticum aestivum L.) and two varieties of durum wheat (Triticum turgidum L.) were used in two separate field experiments in 2009-2010 at the Experimental Station of College of Agriculture in Shiraz University. Each experiment was conducted as a randomized completed block design with three replications. The moisture level in one of the experiments was optimum ( $100 \%$ field capacity) while the second experiment was conducted under drought stress ( $45 \%$ field capacity). Several biochemical components including enzymatic (catalase, CAT; peroxidase, POD; superoxide dismutase, SOD and ascorbate peroxidase, APX) and non-enzymatic (proline and carotenoids, Car) antioxidant defense systems and some factors of oxidative damage (hydrogen peroxide, $\mathrm{H}_{2} \mathrm{O}_{2}$; lipid peroxidation, LPO and membrane stability index, MSI) were analyzed in the two conditions. Drought stress caused significant increase in enzymatic antioxidant activities, proline content, $\mathrm{H}_{2} \mathrm{O}_{2}$ and LPO content at the flowering stage, while Car content and MSI decreased significantly in all genotypes. Drought tolerant genotypes showed the highest enzymatic and non-enzymatic antioxidants, highest MSI and the lowest $\mathrm{LPO}$ and $\mathrm{H}_{2} \mathrm{O}_{2}$. This trend was reversed in susceptible genotypes. The enzymatic antioxidants had higher correlation than non-enzymatic with oxidative stress factors and yield stability index (YSI). POD showed the highest positive correlation with MSI and the highest negative correlation with LPO. $\mathrm{H}_{2} \mathrm{O}_{2}$ and MSI showed the highest correlation with YSI. In present study, Kavir and Alamut varieties were selected respectively as the most tolerant and susceptible genotypes.
\end{abstract}

Keywords: wheat, drought stress, enzymatic and non-enzymatic antioxidants, oxidative damage

\section{Introduction}

Drought stress is one of the major factors limiting plant growth and crop productivity in arid and semi-arid regions and with increasing global climate change making the situation more serious. (Golestani and Assad, 1998; Ahmadi et al., 2010) Much of the injury to plants caused by stress exposure is associated with oxidative damage at the cellular level. However in certain tolerant crop plants morpho-physiological and metabolic changes occur in response to drought, which contribute towards adaptation to such unavoidable environmental constraints (Sairam \& Sirvastava, 2001).

Wheat is a staple food for more than $35 \%$ of the world population and it is also the first grain crop in Iran (Mohammadi et al., 2006). Wheat often experiences drought stress conditions during crop cycle. Thus, improvement of wheat productive for drought tolerance is a major objective in plant breeding programs for arid and semi-arid regions (Shao et al., 2005; Ahmadizadeh et al., 2011).

Drought stress results in stomata closure, which limits $\mathrm{CO}_{2}$ concentration in leaf mesophyll tissue and reduces $\mathrm{NADP}^{+}$regeneration by the Calvin Cycle. These adverse conditions increase the rate of reactivated oxygen species (ROS) such as hydrogen peroxide $\left(\mathrm{H}_{2} \mathrm{O}_{2}\right)$, superoxide $\left(\mathrm{O}_{2}{ }^{-}\right)$, singlet oxygen $\left({ }^{1} \mathrm{O}_{2}\right)$ and hydroxyl $(\mathrm{OH})$ radicals by enhanced leakage of electrons toward molecular oxygen during photosynthetic and respirator processes (Foyer et al., 1994). These ROS can cause damage to membrane lipids, proteins and DNA leading to cell death (Cadenas, 1989). Plants process very efficient enzymatic (superoxide distumase, SOD; catalase, CAT; ascorbate Peroxidase, APX; Peroxidase, POD and glutathione reductase, GR) and non-enzymatic (carotenoids, ascorbic acid, glutathione and proline) antioxidant defense systems which protect cell and subcellular systems against oxidative damages by scavenging of ROS (Dhindsa et al., 1981; Mittler, 2002). SOD catalyzes the 
dismutation of superoxide into oxygen and hydrogen peroxide (Alscher et al., 2002). $\mathrm{H}_{2} \mathrm{O}_{2}$ can be eliminated by CAT, APX and POD (Asada, 1999; Ramachandra et al., 2004). Carotenoid a lipid soluble antioxidant plays a multitude of functions in plant metabolism including oxidative stress tolerance (Sarvajeet \& Narendra, 2010). Accumulation of protective solutes like proline and glycine betaine is a unique plant response to drought stress. Also proline is considered as a potent antioxidant and potential inhibitor of programmed cell death (Bates et al., 1973; Pireivatloum et al., 2010). The objective of the present study was to understand the influence of drought stress on oxidative damage, enzymatic and non-enzymatic antioxidant systems in tolerant, intermediate and susceptible wheat genotypes and also identify the effective biochemical traits in the screening tolerant genotypes to drought.

\section{Materials and Methods}

\subsection{Plant Material and Experimental Conditions}

Eighteen bread wheat genotypes (Triticum aestivum L.) including six drought tolerant genotypes (Azar2, Pishtaz, Toos, Chamran, Kavir and Koohdasht), six intermediate (Roshan, Alvand, Tabasi, Niknejad, cross adl and Darab2) and six susceptible (Shiraz, Shiroudi, Flat, Bahar, Zarin and Alamut) and two durum wheat genotypes (Triticum turgidum L.), Simareh and Yavarus, were also used in two separate field experiments in 2009-2010 at the Experimental Station of College of Agriculture in Shiraz University $\left(52^{\circ} 46^{\prime}\right.$ E, $29^{\circ} 50^{\prime} \mathrm{N}$, altitude $1,810 \mathrm{~m}$ above sea level). Each experiment was conducted as a randomized completed block design with three replications. Each plot consisted of six $4 \mathrm{~m}$ long rows spaced $30 \mathrm{~cm}$ apart. The four middle rows were left intact for grain yield determination, and the two outside rows were used for sampling. The moisture level in one of the experiments was optimum (100\% field capacity) while the second experiment was conducted under drought stress (45\% field capacity), (Table 2). The amount of water needed for irrigation was calculated from the method of Avja and Michael (1987). The characteristics of soil and climates at the experimental station during 2009-2010 are shown in Table 1 and 2 respectively. Flag leaves of flowering stage in two experiments were harvested, weighted and frozen at $-70^{\circ} \mathrm{C}$ for later measurement of biochemical traits.

Table 1. Physical and chemical properties of soil used in the experiments

\begin{tabular}{lcccccccccccc}
\hline Soil characteristic & $\mathrm{P}^{\dagger}$ & $(\mathrm{mg} / \mathrm{kg})$ & $\mathrm{N}$ & $(\%)$ & $\mathrm{K}$ & $(\mathrm{mg} / \mathrm{kg})$ & $\mathrm{OC}$ & $(\%)$ & $\mathrm{EC}$ & $(\mathrm{dS} / \mathrm{m})$ & $\mathrm{pH}$ & Texture \\
\hline Values & 15 & 15 & & 581 & 1.36 & & 0.563 & 7.6 & sandy clay \\
\hline
\end{tabular}

†- P, Phosphorus; N, Nitrogen; K, Potassium; OC, Organic Carbon; EC, Electrical Conductivity, pH, level of acidity.

Table 2. Mean temperature, precipitation distribution and total irrigation for each experiment

\begin{tabular}{rccccc}
\hline Month & Year & $\begin{array}{c}\text { Mean temperature } \\
\left({ }^{\circ} \mathrm{C}\right)\end{array}$ & Rainfall $(\mathrm{mm})$ & \multicolumn{2}{c}{ Irrigation $(\mathrm{mm})$} \\
\cline { 5 - 6 } & & 10.62 & 10.5 & 131 & No- stressed \\
November & 2009 & 5.66 & 129 & - & - \\
December & 2009 & 5.1 & 17 & - & - \\
January & 2009 & 6.13 & 54.5 & - & - \\
February & 2010 & 10.4 & 37.5 & 43 & 19.35 \\
March & 2010 & 12.23 & 24.5 & 70.42 & 31.69 \\
April & 2010 & 17.04 & 13 & 113.1 & 50.89 \\
May & 2010 & 22.58 & 0 & 60.4 & 27.18 \\
June & 2010 & & 286 & 417.92 & 260.11 \\
\hline Total & & & & 703.92 & 546.11 \\
\hline Total water used & & & & &
\end{tabular}

\subsection{Grain Yield and Yield Stability Index Assay}

Grain yield was recorded at physiological maturity stage. The physiological maturity stage was considered when $90 \%$ of seed changed color from green to yellowish and stopped photosynthetic activity. Yield stability index (YSI) was calculated using the formula suggested by Bouslama and Schapaugh (1984) as:

$$
\mathrm{YSI}=\mathrm{Ys} / \mathrm{Yp}
$$

Where, Ys and Yp represent yield under stress and non-stress conditions, respectively. 


\subsection{Enzymatic Antioxidants Assay}

Frozen leaf samples $(0.5 \mathrm{~g})$ were used for enzyme extraction. Samples were homogenized with $2 \mathrm{~mL}$ of $50 \mathrm{mM}$ phosphate buffer ( $\mathrm{pH}$ 7.2) using a pre-chilled mortar and pestle. Phosphate buffer contained $1 \mathrm{mM}$ EDTA, $1 \mathrm{mM}$ PMSF, and 1\% PVP-40. Then the homogenates were centrifuged at $4^{\circ} \mathrm{C}$ and $15,000 \times \mathrm{g}$ for $15 \mathrm{~min}$.

Superoxide dismutase (SOD, EC 1.15.1.1) activity was assayed by measuring its ability to inhibit the photoreduction of nitroblue tetrazolium (NBT) using the method of Beauchamp and Fridovich (1971). The reaction mixture contained: $50 \mathrm{mM}$ phosphate buffer ( $\mathrm{pH}$ 7.8), $0.1 \mathrm{mM}$ EDTA, $13 \mathrm{mM}$ methionine, $75 \mu \mathrm{M}$ nitroblue tetrazolium (NTB), $2 \mu \mathrm{M}$ riboflavin and $100 \mu \mathrm{l}$ of the supernatant. Riboflavin was added as the last component and the reaction was initiated by placing the tubes under two $15 \mathrm{~W}$ fluorescent lamps. The reaction was terminated after $15 \mathrm{~min}$ by removing the reaction tubes from the light source. Non-illuminated and illuminated reac- tions without supernatant served as calibration standards. Reaction products were measured at $560 \mathrm{~nm}$. One unit of SOD activity was defined as the amount of enzyme that inhibited 50 nitroblue tetrazolium (NBT) photoreduction.

Ascorbate peroxidase (APX; EC 1.11.1.11) activity was measured using the method of Nakano and Asada (1981). The assay mixture contained of $50 \mathrm{mM}$ potassium phosphate buffer ( $\mathrm{pH} 7.0)$ containing $0.5 \mathrm{mM}$ ascorbic acid, $0.15 \mathrm{mM} \mathrm{H}_{2} \mathrm{O}_{2}, 0.1 \mathrm{mM}$ EDTA, and $50 \mu \mathrm{L}$ of enzyme extract (supernatant). Ascorbate peroxidase was spectrophotometrically assayed following a decrease in the absorbance at $290 \mathrm{~nm}$. One unit of APX oxidises 1 $\mathrm{mM}$ ascorbic acid in $1 \mathrm{~min}$ at $25^{\circ} \mathrm{C}$.

Catalase (CAT, EC 1.11.1.6) activity was measured by following the reduction of $\mathrm{H}_{2} \mathrm{O}_{2}\left(\varepsilon=39.4 \mathrm{mM}^{-1} \mathrm{~cm}^{-1}\right)$ at $240 \mathrm{~nm}$ according to the method of Dhindsa et al. (1981). The assay solution contained $50 \mathrm{mM}$ potassium phosphate buffer $(\mathrm{pH} 7.0)$ and $15 \mathrm{mM} \mathrm{H}_{2} \mathrm{O}_{2}$. The reaction was started by the addition of $100 \mu 1$ enzyme extract to the reaction mixture and the change in absorbance was followed $1 \mathrm{~min}$ after the start of the reaction. One unit of activity was considered as the amount of enzyme which decomposes $1 \mathrm{mM}$ of $\mathrm{H}_{2} \mathrm{O}_{2}$ in one minute.

Peroxidase (POD, EC 1.11.1.7) activity was determined according to the method of Chance and Maehly (1955). The tetraguaiacol formed in the reaction has a maximum absorption at $470 \mathrm{~nm}$ and thus the reaction can be readily followed spectrophotometrically. The enzyme was assayed in a solution containing $50 \mathrm{mM}$ phosphate buffer ( $\mathrm{pH} \mathrm{7.0),} 5 \mathrm{mM} \mathrm{H}_{2} \mathrm{O}_{2}$ and $13 \mathrm{mM}$ guaiacol. The reaction was initiated by adding of $33 \mu 1$ enzyme extract at $25^{\circ} \mathrm{C}$. One unit of enzyme was calculated on the basis of the formation of guaiacol to tetraguaiacol for $1 \mathrm{~min}$.

\subsection{Non-enzymatic Antioxidants Assay}

The content of proline was extracted and determined by the method of Bates et al. (1973). Leaf tissues $(0.5 \mathrm{~g})$ were homogenized in $3 \%$ sulfosalicylic acid and the homogenate was centrifuged at $3,000 \times \mathrm{g}$ for $10 \mathrm{~min}$. The supernatant was treated with acetic acid and ninhydrin, boiled for $1 \mathrm{~h}$, and then the absorbance was determined at $520 \mathrm{~nm}$. Proline concentration was calculated with a standard curve and expressed as $\mu \mathrm{molg}^{-1}$ fresh mass.

The amount of carotenoids (Car) was determined according to Lichtenthaler and Wellburn (1983). Leaf tissues $(0.5 \mathrm{~g})$ were homogenized in acetone $(80 \%)$. Extract was centrifuged at $3,000 \times \mathrm{g}$ and absorbance was recorded at $646.8 \mathrm{~nm}$ and $663.2 \mathrm{~nm}$ for chlorophyll assay and $470 \mathrm{~nm}$ for Car determine by spectrophotometer. Car and Pigments content were calculated due to the following formulae:

$$
\begin{gathered}
\text { Chl a }=\left(12.25 \mathrm{~A}_{663.2}-2.79 \mathrm{~A}_{646.8}\right) \\
\mathrm{Chl} \mathrm{b}=\left(21.21 \mathrm{~A}_{646.8}-5.1 \mathrm{~A}_{663.2}\right) \\
\mathrm{Car}=\left(1000 \mathrm{~A}_{470}-1.8 \mathrm{Chl} \mathrm{a}-85.02 \mathrm{Chl} \mathrm{b}\right) / 198
\end{gathered}
$$

\subsection{Oxidative Damage Assay}

Hydrogen peroxide $\left(\mathrm{H}_{2} \mathrm{O}_{2}\right)$ content was determined according to Alexieva et al. (2001). Leaf tissue $(0.5 \mathrm{~g})$ was homogenized in ice bath with $5 \mathrm{~cm}^{3}$ of cold $0.1 \%(\mathrm{~m} / \mathrm{v})$ trichloroacetic acid (TCA). The homogenate was centrifuged $\left(10,000 \times \mathrm{g}, 20 \mathrm{~min}, 4^{\circ} \mathrm{C}\right)$ and $0.5 \mathrm{~cm}^{3}$ of the supernatant was added to $0.5 \mathrm{~cm}^{3}$ of $100 \mathrm{mM}$ potassium phosphate buffer ( $\mathrm{pH} 7.0$ ) and $1 \mathrm{~cm}^{3}$ of $1 \mathrm{M} \mathrm{KI}$. The absorbance was read at $390 \mathrm{~nm}$. The concentration of $\mathrm{H}_{2} \mathrm{O}_{2}$ was determined using a standard curve plotted with a known concentration of $\mathrm{H}_{2} \mathrm{O}_{2}$.

Lipid peroxidation (LPO) rates in plant tissues were determined by measuring the malondialdehyde (MDA) according to the method of Heath and Packer (1968). MDA content was determined with thiobarbituric acid (TBA) reaction. $0.5 \mathrm{~g}$ tissue sample was homogenized in $5 \mathrm{ml} 0.1 \%$ trichloroacetic acid (TCA). The homogenate was centrifuged at $10,000 \times \mathrm{g}$ for $10 \mathrm{~min} .4 \mathrm{ml}$ of $20 \%$ TCA containing $0.5 \%$ TBA was added to $1 \mathrm{ml}$ aliquot of the supernatant. The mixture was heated at $95^{\circ} \mathrm{C}$ for $30 \mathrm{~min}$ and quickly cooled in ice bath. After centrifugation at $10,000 \times \mathrm{g}$ for $10 \mathrm{~min}$. The non-specific absorbance of the supernatant at $600 \mathrm{~nm}$ was subtracted from the 
maximum absorbance at $532 \mathrm{~nm}$ for MDA measurement. The level of lipid peroxidation was expressed as $\mu$ mol of MDA formed using an extinction coefficient of $155 \mathrm{mM}^{-1} \mathrm{~cm}^{-1}$.

Membrane stability index (MSI) estimated according to Sairam (1994). Two sets of leaf tissues (0.1 g) were placed in $10 \mathrm{ml}$ of double-distilled water. One set was kept at $40^{\circ} \mathrm{C}$ for $30 \mathrm{~min}$ and its conductivity recorded using a conductivity bridge $\left(\mathrm{C}_{1}\right)$. The second set was kept in a boiling water bath $\left(100^{\circ} \mathrm{C}\right)$ for 10 min and its conductivity also recorded $\left(\mathrm{C}_{2}\right)$. The membrane stability index was calculated as:

$$
\operatorname{MSI}=\left[1-\left(\mathrm{C}_{1} / \mathrm{C}_{2}\right)\right] \times 100
$$

\subsection{Statistical Analysis of Data}

Analysis of variance and Pearson correlations coefficients in all the measurements were conducted by SPSS 16. Means were separated using Tukey's test at $\mathrm{P}<0.05$. To compare the effects of stress and non-stress, and genotypes by moisture conditions interaction, a combined analysis of variance was used.

\section{Results and Discussion}

\subsection{Enzymatic Antioxidants Defense Response}

The results of the present study showed that considerable variations among genotypes for antioxidant activity were observed when grown under drought stress and non-stress conditions (Table 3). Peroxidase (POD) activity increased significantly $(\mathrm{P}<0.01)$ under water stress condition. POX is one of the major enzymes that have a role in the biosynthesis of lignin and defense against water stress by scavenges $\mathrm{H}_{2} \mathrm{O}_{2}$ in chloroplasts (Mittler, 2002; Sarvajeet \& Narendra, 2010). The highest POD activity were observed in genotypes Toos, Pishtaz, Chamran, Kavir and Koohdasht (drought tolerance, group 1), and the lowest activity in Bahar, Shiraz, Zarin, Alamut and Shiroudi (susceptible, group 3) under water stress condition. The ratio was intermediate in Alvand, Niknejad Cross Adl and Roshan (intermediate tolerance, group 2). From Figure 1, we observed that genotypes in group1, group 2 and group 3 had the highest, intermediate and lowest yield stability index (YSI), respectively.

Table 3. Changes in enzymatic antioxidant (catalase, CAT; superoxide dismutase, SOD; peroxidase, POD and ascorbate peroxidase, APX) activity and non-enzymatic antioxidant (Proline and carotenoids, Car) content in wheat genotypes in response to drought stress.

\begin{tabular}{|c|c|c|c|c|c|c|c|c|c|c|c|c|}
\hline \multirow[t]{2}{*}{ Genotypes } & \multicolumn{2}{|c|}{$\begin{array}{c}\text { CAT } \\
\left(\mathrm{Ug}^{-1} \mathrm{FW}\right) \\
\end{array}$} & \multicolumn{2}{|c|}{$\begin{array}{c}\text { SOD } \\
\left(\mathrm{Ug}^{-1} \mathrm{FW}\right) \\
\end{array}$} & \multicolumn{2}{|c|}{$\begin{array}{c}\text { POD } \\
\left(\mathrm{Ug}^{-1} \mathrm{FW}\right) \\
\end{array}$} & \multicolumn{2}{|c|}{$\begin{array}{c}\text { APX } \\
(\mathrm{Ug}-1 \mathrm{FW}) \\
\end{array}$} & \multicolumn{2}{|c|}{$\begin{array}{c}\text { Proline } \\
\left(\mu \mathrm{mol} \mathrm{g}{ }^{-1} \mathrm{FW}\right)\end{array}$} & \multicolumn{2}{|c|}{$\begin{array}{c}\text { Car } \\
\left(\mathrm{mg} \mathrm{g}^{-1} \mathrm{FW}\right)\end{array}$} \\
\hline & Non-stress & Stress & Non-stress & Stress & Non-stress & Stress & Non-stress & Stress & Non-stress & Stress & Non-stress & Stress \\
\hline Bahar & $39.1 \mathrm{j}-1$ & $44.2 \mathrm{c}-\mathrm{k}$ & $370.8 \mathrm{j}-\mathrm{o}$ & $426.1 \mathrm{~g}-\mathrm{k}$ & $56.1 \mathrm{o}-\mathrm{q}$ & $60.51-p$ & 138.5 k-n & $159.4 \mathrm{f}-\mathrm{k}$ & $4 / 84 \mathrm{~h}$ & $27 / 31$ b-e & $7 / 47 \mathrm{a}$ & $5 / 91 \mathrm{c}-\mathrm{i}$ \\
\hline Chamran & $37.8 \mathrm{kl}$ & $48.5 \mathrm{a}-\mathrm{e}$ & $354.1 \mathrm{k}-\mathrm{o}$ & $640.7 \mathrm{~b}$ & 86.8 b-d & $94.8 \mathrm{ab}$ & $148.7 \mathrm{~g}-\mathrm{n}$ & $206.0 \mathrm{a}-\mathrm{d}$ & $8 / 83 \mathrm{f}-\mathrm{h}$ & $23 / 03 \mathrm{c}-\mathrm{e}$ & $5 / 53 \mathrm{~d}-\mathrm{m}$ & $4 / 87 \mathrm{~g}-\mathrm{o}$ \\
\hline Cross Adl & 34.01 & $42.3 \mathrm{e}-\mathrm{k}$ & $339.7 \mathrm{~m}-\mathrm{p}$ & 493.9 c-g & $54.3 \mathrm{pq}$ & $73.2 \mathrm{e}-\mathrm{j}$ & $130.7 \mathrm{mn}$ & $148.9 \mathrm{~g}-\mathrm{n}$ & $4 / 15 \mathrm{~h}$ & $33 / 37$ a-c & $7 / 43 \mathrm{a}$ & $4 / 90 \mathrm{~g}-\mathrm{O}$ \\
\hline Shiraz & $39.3 \mathrm{j}-1$ & $44.8 \mathrm{~b}-\mathrm{j}$ & 339.5 m-p & $352.5 \mathrm{k}-\mathrm{o}$ & 62.9 i-p & 63.2 i-p & $140.7 \mathrm{j}-\mathrm{n}$ & $168.9 \mathrm{~d}-\mathrm{i}$ & $3 / 10 \mathrm{~h}$ & $35 / 82 \mathrm{ab}$ & $6 / 36 a-f$ & 4/86 h-o \\
\hline Kavir & $39.2 \mathrm{j}-1$ & $49.0 \mathrm{a}-\mathrm{d}$ & $315.0 \mathrm{n}-\mathrm{p}$ & $560.7 \mathrm{c}$ & $48.8 \mathrm{q}$ & $88.2 \mathrm{a}-\mathrm{d}$ & $144.9 \mathrm{i}-\mathrm{n}$ & $223.5 \mathrm{a}$ & $3 / 20 \mathrm{~h}$ & $36 / 11 \mathrm{ab}$ & $6 / 02 \mathrm{a}-\mathrm{f}$ & $6 / 14 a-f$ \\
\hline Shiroudi & $37.9 \mathrm{kl}$ & $47.3 \mathrm{a}-\mathrm{g}$ & 330.9 m-p & $377.5 \mathrm{i}-\mathrm{n}$ & $61.9 \mathrm{k}-\mathrm{p}$ & $69.4 \mathrm{f}-\mathrm{m}$ & $151.5 \mathrm{f}-\mathrm{n}$ & $154.0 \mathrm{f}-\mathrm{m}$ & $4 / 49 \mathrm{~h}$ & $22 / 73 \mathrm{c}-\mathrm{e}$ & $3 / 36 \mathrm{pq}$ & $2 / 66 \mathrm{q}$ \\
\hline Koohdasht & $41.4 \mathrm{~g}-\mathrm{k}$ & $51.9 \mathrm{a}$ & 319.4 n-p & $687.8 \mathrm{ab}$ & $58.9 \mathrm{~m}-\mathrm{q}$ & $91.1 \mathrm{ac}$ & $158.8 \mathrm{f}-1$ & $209.0 \mathrm{a}-\mathrm{d}$ & $5 / 05 \mathrm{~h}$ & $33 / 06$ a-c & $7 / 32 \mathrm{ab}$ & $7 / 05$ a-c \\
\hline Darab2 & $43.6 \mathrm{c}-\mathrm{k}$ & $49.8 \mathrm{a}-\mathrm{c}$ & 397.6 h-m & $502.0 \mathrm{c}-\mathrm{f}$ & $71.6 \mathrm{f}-\mathrm{k}$ & $95.0 \mathrm{ab}$ & $172.3 \mathrm{~d}-\mathrm{h}$ & $216.9 \mathrm{ab}$ & $3 / 27 \mathrm{~h}$ & 28/75 a-e & $4 / 38 \mathrm{k}-\mathrm{p}$ & $3 / 79$ o-q \\
\hline Seimare & $40.3 \mathrm{~h}-1$ & $51.6 \mathrm{a}$ & $325.5 \mathrm{~m}-\mathrm{p}$ & $673.8 \mathrm{ab}$ & $54.7 \mathrm{pq}$ & 78.9 d-f & $141.5 \mathrm{j}-\mathrm{n}$ & 194.9 b-d & $5 / 78 \mathrm{~h}$ & $40 / 15 \mathrm{a}$ & 6/03 b-h & $5 / 18 \mathrm{f}-\mathrm{n}$ \\
\hline Falat & 34.81 & $39.9 \mathrm{j}-1$ & $345.1 \mathrm{~m}-\mathrm{p}$ & 389.8 h-n & 62.4 k-p & $74.3 \mathrm{e}-\mathrm{h}$ & $135.0 \mathrm{k}-\mathrm{n}$ & 148.0 g-n & $6 / 90 \mathrm{~g}-\mathrm{h}$ & $22 / 56 \mathrm{c}-\mathrm{e}$ & $5 / 60 \mathrm{~d}-1$ & 4/49 j-p \\
\hline Niknejad & $38.9 \mathrm{j}-1$ & $45.9 \mathrm{a}-\mathrm{i}$ & $421.9 \mathrm{~g}-1$ & $524.0 \mathrm{~cd}$ & $65.5 \mathrm{~h}-\mathrm{o}$ & $83.4 \mathrm{c}-\mathrm{e}$ & $127.8 \mathrm{mn}$ & $165.6 \mathrm{e}-\mathrm{j}$ & $4 / 60 \mathrm{~h}$ & $21 / 99$ c-e & $6 / 37 a-f$ & 4/70 i-o \\
\hline Yavarus & $39.8 \mathrm{i}-1$ & $47.9 \mathrm{a}-\mathrm{f}$ & $326.7 \mathrm{~m}-\mathrm{p}$ & $449.5 \mathrm{~d}-\mathrm{i}$ & 63.7 h-p & $69.7 \mathrm{f}-1$ & 148.8 g-n & $190.1 \mathrm{c}-\mathrm{e}$ & $5 / 23 \mathrm{~h}$ & $39 / 70 \mathrm{a}$ & 4/65 j-p & $6 / 29 a-h$ \\
\hline Roshan & $38.5 \mathrm{j}-1$ & $48.8 \mathrm{a}-\mathrm{d}$ & 301.0 op & $522.3 \mathrm{~cd}$ & $63.47 \mathrm{i}-\mathrm{p}$ & $83.5 \mathrm{c}-\mathrm{e}$ & $143.6 \mathrm{i}-\mathrm{n}$ & $172.7 \mathrm{~d}-\mathrm{g}$ & $7 / 38$ g-h & $33 / 23$ a-c & $5 / 69$ d-k & 5/36 e-m \\
\hline Azar2 & 40.4 h-1 & $47.2 \mathrm{a}-\mathrm{g}$ & $337.6 \mathrm{~m}-\mathrm{p}$ & $520.1 \mathrm{~cd}$ & $72.2 \mathrm{f}-\mathrm{k}$ & $83.3 \mathrm{c}-\mathrm{e}$ & $141.6 \mathrm{j}-\mathrm{n}$ & $174.5 \mathrm{~d}-\mathrm{g}$ & $8 / 52 \mathrm{f}-\mathrm{h}$ & 28/01 a-e & $5 / 79 \mathrm{c}-\mathrm{j}$ & $5 / 47 \mathrm{~d}-\mathrm{m}$ \\
\hline Tabasi & $39.3 \mathrm{j}-1$ & $46.4 \mathrm{a}-\mathrm{h}$ & $275.9 \mathrm{p}$ & $434.2 \mathrm{f}-\mathrm{j}$ & $73.7 \mathrm{e}-\mathrm{i}$ & $71.5 \mathrm{f}-\mathrm{k}$ & $133.01-n$ & $158.7 \mathrm{f}-1$ & $9 / 42 \mathrm{f}-\mathrm{h}$ & $31 / 40$ a-d & $5 / 21 \mathrm{f}-\mathrm{n}$ & $3 / 34 p$ \\
\hline Zarin & $41.5 \mathrm{f}-\mathrm{k}$ & $41.4 \mathrm{~g}-\mathrm{k}$ & $347.81-\mathrm{p}$ & 398.5 h-m & $58.5 \mathrm{n}-\mathrm{q}$ & 64.2 h-p & $127.7 \mathrm{n}$ & $151.0 \mathrm{f}-\mathrm{n}$ & $3 / 99 \mathrm{~h}$ & $19 / 18 \mathrm{~d}-\mathrm{g}$ & $6 / 03 \mathrm{~b}-\mathrm{i}$ & 4/35 1-p \\
\hline Alamot & $40.1 \mathrm{~h}-1$ & $43.9 \mathrm{c}-\mathrm{k}$ & 338.3 m-p & $378.3 \mathrm{i}-\mathrm{n}$ & 66.9 h-n & 68.1 g-n & 146.2 g-n & $157.3 \mathrm{f}-1$ & $4 / 66 \mathrm{~h}$ & $18 / 96 \mathrm{e}-\mathrm{g}$ & 6/76 a-d & $4 / 01 \mathrm{n}-\mathrm{p}$ \\
\hline Toos & $43.3 \mathrm{~d}-\mathrm{k}$ & $50.9 \mathrm{ab}$ & $339.8 \mathrm{~m}-\mathrm{p}$ & $516.4 \mathrm{c}-\mathrm{e}$ & $69.0 \mathrm{f}-\mathrm{n}$ & $98.7 \mathrm{a}$ & $157.6 \mathrm{f}-1$ & $206.8 \mathrm{a}-\mathrm{d}$ & $5 / 26 \mathrm{~h}$ & $27 / 26$ b-e & $6 / 20 \mathrm{a}-\mathrm{g}$ & $6 / 27 \mathrm{a}-\mathrm{f}$ \\
\hline Pishtaz & $37.8 \mathrm{kl}$ & $44.9 \mathrm{~b}-\mathrm{j}$ & $455.7 \mathrm{~d}-\mathrm{h}$ & $725.2 \mathrm{a}$ & $73.6 \mathrm{e}-\mathrm{i}$ & $94.9 \mathrm{ab}$ & 133.4 k-n & $211.1 \mathrm{a}-\mathrm{d}$ & $4 / 07 \mathrm{~h}$ & $20 / 50 \mathrm{~d}-\mathrm{f}$ & 6/60 a-e & $5 / 77 \mathrm{c}-\mathrm{j}$ \\
\hline Alvand & $37.9 \mathrm{kl}$ & $42.6 \mathrm{~d}-\mathrm{k}$ & $332.4 \mathrm{~m}-\mathrm{p}$ & $443.7 \mathrm{e}-\mathrm{j}$ & $78.4 \mathrm{~d}-\mathrm{g}$ & $85.2 \mathrm{~b}-\mathrm{d}$ & $158.1 \mathrm{f}-1$ & $175.8 \mathrm{~d}-\mathrm{f}$ & $5 / 74 \mathrm{~h}$ & $24 / 80 \mathrm{~b}-\mathrm{e}$ & $6 / 44$ a-f & $4 / 23 \mathrm{~m}-\mathrm{p}$ \\
\hline Average & $39.7 \mathrm{~b}$ & $46.5 \mathrm{a}$ & $345.7 \mathrm{~b}$ & $500.8 \mathrm{a}$ & $65.2 \mathrm{~b}$ & $79.5 \mathrm{a}$ & $143.9 \mathrm{~b}$ & $179.6 \mathrm{a}$ & $5 / 42 \mathrm{~b}$ & $27 / 90 \mathrm{a}$ & $5 / 97 \mathrm{a}$ & $4 / 99 \mathrm{~b}$ \\
\hline
\end{tabular}

Means of three replicates followed by the same letter in each column and two columns (non-stress and drought stress) related to same indicator are not significantly different according to Tukey's test (probability level of \%5). 
The results clearly showed that POD is a suitable indicator for drought resistant. Shao et al. (2005) also observed variation in peroxidase activity in wheat genotypes and suggested that water stress tolerance was closely associated with POD activities.

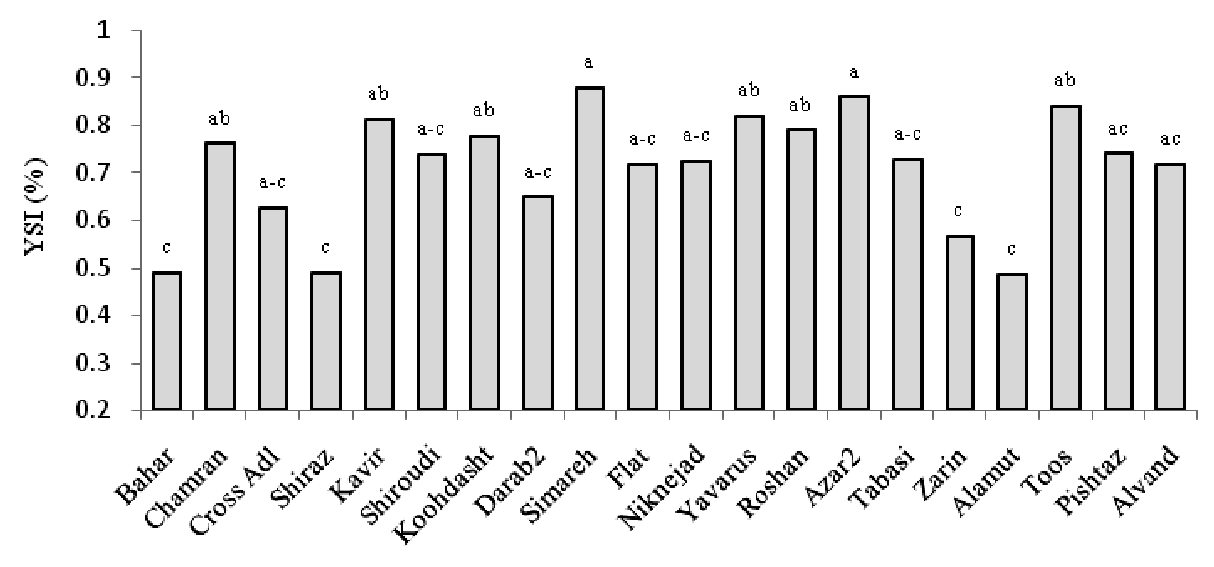

Figure 1. Yield stability index (YSI) in wheat genotypes at the flowering stage. Different letters indicate significant differences between means of three replicates according to Tukey's test (probability level of \%5)

Catalase (CAT) is one of the highest turnover rates for all enzymes with the potential to directly dismutate $\mathrm{H}_{2} \mathrm{O}_{2}$ into $\mathrm{H}_{2} \mathrm{O}$ and $\mathrm{O}_{2}$ and is indispensable for ROS detoxification in peroxisomes during stress conditions (Asada, 1999; Sairam \& Srivastava, 2001). In this study, CAT activity significantly $(\mathrm{P}<0.01)$ increased under water stress condition (Table 3). CAT activity also rose in all genotypes with exception of Zarin. Koohdasht exhibited the highest CAT activity under both control and water stress conditions. Tolerant genotypes (group 1) including Koohdasht, Simareh, Toos, Azar2, Chamran and Kavir indicated higher CAT activity among these 20 genotypes (Table 3). The higher CAT activity in drought tolerant genotypes demonstrated their superior tolerance mechanisms in terms of $\mathrm{H}_{2} \mathrm{O}_{2}$ scavenging compared with the other genotypes. Our results are consistent with other works reporting the increased CAT activity in response to water stress in barley (Salekjalali et al., 2012), wheat (Ahmadizadeh et al., 2011), maize (Ahmadi et al., 2010) oilseed rape (Abedi \& Pakniyat, 2010), tomato (Behnamnia et al., 2009), been (Zlatev et al., 2006) and mulberry (Ramachandra et al., 2004).

Ascorbate peroxidase (APX) activity also enhanced significantly $(\mathrm{P}<0.01)$ under water stress condition (Table $3)$. In our study, the differences in APX activity of genotypes were significant $(\mathrm{P}<0.01)$ in both stress and non-stress conditions. APX is thought to play the most important role in scavenging ROS and protecting cells in all plants (Nakano \& Asada, 1981). APX has a higher affinity for $\mathrm{H}_{2} \mathrm{O}_{2}$ than CAT and POD, thus, it may have a more essential role in the management of ROS during stress conditions (Sarvajeet \& Narendra, 2010). From table 3, it was observed that genotypes Kavir, Koohdasht, Toos, Pishtaz and Chamran (group 1) expressed higher APX activities under water stress. Genotypes Alvand, Niknejad, Tabase and Roshan (group 2) had intermediate APX activities and genotypes Flat, Bahar, Shiraz, Zarin, Alamut and Shiroudi (group 3) performed lower APX activities. Among 20 wheat genotypes, Kavir had the top APX activities under drought stress. Renu and Devarshi (2007) reported that drought tolerant genotypes of wheat had the highest APX activity under drought condition.

Superoxide dismutase (SOD) activity was also influenced by water stress (Table 3). SOD activity increased significantly $(\mathrm{P}<0.01)$ under water stress condition. The lowest SOD were observed in Shiraz, Flat, Bahar, Zarin, Alamut and Shiroudi (group 3), and the highest in Pishtaz, Kavir, Koohdasht, Toos and Chamran (group 1) while Alvand, Niknejad, Tabase, Darab2 and Cross Adl (group 2) showed intermediate response under stress condition. Comparing 1, 2, and 3 group, genotypes Pishtaz and Shiroudi had the highest and lowest SOD activity among all genotypes (Table 3). Efficient destruction of $\mathrm{O}_{2}{ }^{-}$and $\mathrm{H}_{2} \mathrm{O}_{2}$ in plant cells requires the concerted action of antioxidants. SOD detoxifies superoxide anion free radicals by forming $\mathrm{H}_{2} \mathrm{O}_{2}$, which is harmful to the membrane, chloroplast, nucleic acids and proteins. $\mathrm{H}_{2} \mathrm{O}_{2}$ can be eliminated by CAT, POD and APX (Alscher et al., 2002; Amjad et al., 2011). Thus, higher SOD activity in tolerance genotypes as compared to susceptible can be explained that susceptible genotypes had less efficient systems in $\mathrm{O}_{2}{ }^{--}$scavenging under drought conditions. 


\subsection{Non-enzymatic Antioxidants Defense Response}

Results in Table 3 demonstrated that water stress induced accumulation of proline in flag leaves of wheat. Under drought condition, free proline content significantly $(\mathrm{P}<0.05)$ increased in all genotypes. Increase in proline accumulation observed under water stress in all genotypes was in accordance with the findings of Behnamnia et al. (2009) in tomato, Turkan et al. (2005) in bean and Ramachandra et al. 2004 in mulberry. The highest and lowest proline content was observed by Simareh and Alamut respectively. According to Table 3, genotypes Simareh and Alamut had the highest and lowest YSI in all, respectively. Drought resistant genotypes also indicated higher accumulation of proline than sensitive genotypes. Geravandi et al. (2011) reported, proline accumulation varies with degree of drought tolerance in wheat. Thus, it could be used for the evaluation of drought tolerant wheat. Accumulation of proline under water stress protects the cell by balancing the osmotic potential of cytosol with that of vacuole and external environment. Pireivatloum et al. (2010) reported that proline is an important osmolyte to adjust the plant under drought condition. In addition, proline can be considered as potent non-enzymatic antioxidants that plants need to counteract the inhibitory effects of ROS. Therefore, tolerance to drought may be improved by the enhancement of proline content (Turkan et al., 2005).

Carotenoids (Car) are one of the major non-enzymatic antioxidants that has a role in defence against water stress by scavenges of singlet oxygen and suppressing lipid peroxidation in all photosynthetic organisms. Car a lipid soluble antioxidant plays a multitude of functions in plant metabolism including oxidative stress tolerance (Sarvajeet \& Narendra, 2010). In present study, there was a significant $(\mathrm{P}<0.01)$ reduction in Car under water stress in all genotypes (Table 3). The percent reduction in Car were lower in resistant genotypes as compared to susceptible. The highest and lowest Car were observed in Koohdasht and Tabasi under water stress, respectively. Hence comparatively higher Car levels in resistant genotypes demonstrated their tolerance capacity. Higher levels of Car and chlorophyll in tolerant genotypes have also been reported by Salekjalali et al. (2012).

\subsection{Oxidative Damage}

Drought stress lead to the overproduction of reactive oxygen species (ROS) and consequently ROS cause oxidative damage in plants (Cadenas, 1989). Sairam and Sirvastava (2001) observed that much of the injury to plants caused by water stress exposure is associated with oxidative damage at the membrane cell. In present experiment, the hydrogen peroxide $\left(\mathrm{H}_{2} \mathrm{O}_{2}\right)$ accumulation increased significantly $(\mathrm{P}<0.01)$ under water stress condition (Figure 2). $\mathrm{H}_{2} \mathrm{O}_{2}$ is a strong toxic compound produced as a result of the change of the superoxide radical. Also the univalent reduction of superoxide produces $\mathrm{H}_{2} \mathrm{O}_{2}$. The high concentration of $\mathrm{H}_{2} \mathrm{O}_{2}$ is harmful to the cell and the plant, resulting in lipid peroxidation and membrane injury (Assada, 1999; Mittler, 2002). Tolerant genotypes Kavir, Azar2, Pishtaz, Koohdasht, Toos and Chamran (group 1) showed less $\mathrm{H}_{2} \mathrm{O}_{2}$ content than susceptible genotypes Alamut, Flat, Bahar, Shiraz, Zarin and Shiroudi (group 3). Consequently, genotypes Darab2, Alvand, Niknejad, Tabase and Roshan (group 2) had intermediate accumulation of $\mathrm{H}_{2} \mathrm{O}_{2}$ under water stress condition (Figure 2). Our results clearly showed that there was differential accumulation of $\mathrm{H}_{2} \mathrm{O}_{2}$ as well as genotypic variations in $\mathrm{H}_{2} \mathrm{O}_{2}$ scavenging antioxidant in wheat genotypes. These results were similar to works of Behnamnia et al. (2009) in tomato and Alexieva et al. (2001) in wheat.

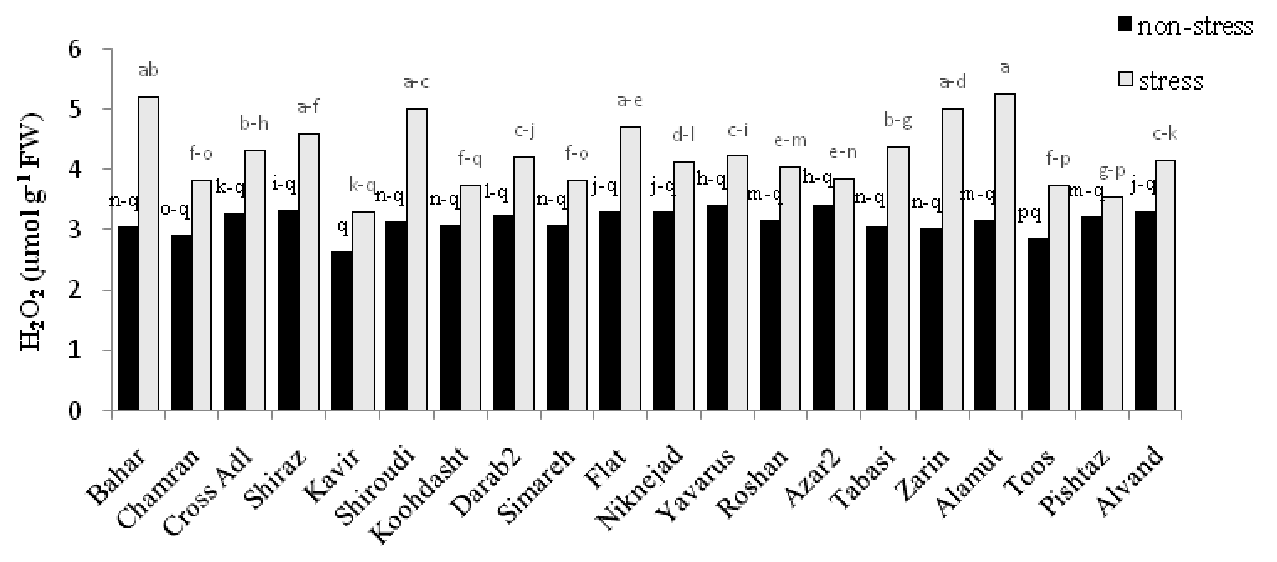

Figure 2. Effect of water stress on hydrogen peroxidase (H2O2) in wheat genotypes. Different letters indicate significant differences between means of three replicates according to Tukey's test (probability level of \%5) 


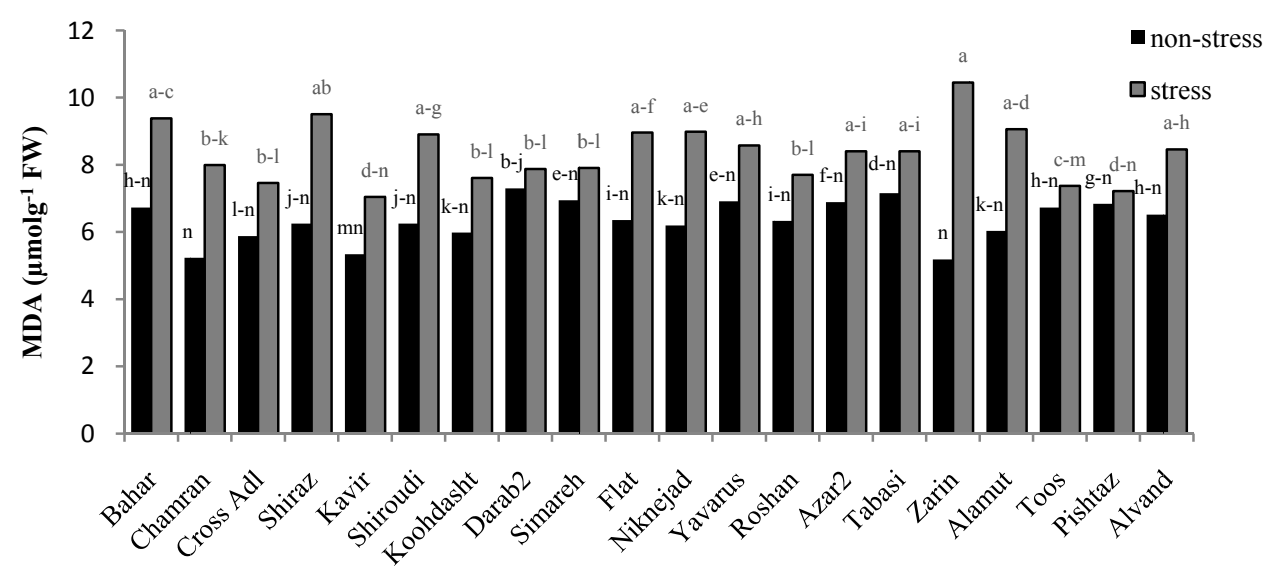

Figure 3. Effect of water stress on lipid peroxidation (MDA content) in wheat genotypes. Different letters indicate significant differences between means of three replicates according to Tukey's test (probability level of \%5)

Lipid peroxidation (LPO) is considered as the most damaging factor in every living organism under various stresses (Renu and Devarshi, 2007). LPO determined as malondialdehyd (MDA) content. Under water stress LPO increased significantly $(\mathrm{P}<0.01)$ in all genotype (Figure 3 ). Increased LPO as a result of oxidative stress and consequently cell membrane injury has also been reported by various works (Zlatev et al., 2006; Turkan et al., 2005; Amjad et al., 2011). Maximum and minimum LPO was observed in Zarin and Kavir, respectively. Kavir also indicated the lowest and highest of $\mathrm{H}_{2} \mathrm{O}_{2}$ content and APX activity respectively in all genotypes. As seen in Figure 3, it was observed that the lowest LPO were observed in tolerance genotypes (group 1) and the highest in susceptible ones (group 3) in stress condition. Several reports indicated that tolerant genotypes had lower $\mathrm{H}_{2} \mathrm{O}_{2}$ content and $\mathrm{LPO}$ under water stress.

Membrane damage is sometimes taken as the major parameter to estimate the level of lipid destruction under various stresses. The degree of cell membrane injury induced by water stress may be easily estimated through measurements of electrolyte leakage from the cells (Sarvajeet \& Narendra, 2010; Ahmadizadeh et al., 2011). Membrane stability index (MSI) significantly decreased under water stress also showed a more decline in susceptible genotype (Figure 4). A decrease in membrane stability reflected the extent of lipid peroxidation caused by reactive oxygen species (Sairam \& Sirvastava, 2001). In Figure 4, the lowest MSI were observed in Zarin and highest in Pishtaz. Zarin and Pishtaz also indicated the highest MDA and SOD, respectively under water stress. In this connection it has been reported that drought stress tolerant and intermediate tolerant genotypes were superior to susceptible ones in maintaining membrane stability and lower LPO under drought stress condition (Amjad et al., 2011). Higher MSI and antioxidant activity, and lower LPO and $\mathrm{H}_{2} \mathrm{O}_{2}$ have been reported in drought tolerant genotypes of wheat (Renu \& Devarshi, 2007), bean (Zlatev et al., 2006) and Mulberry (Ramachandra et al., 2004).

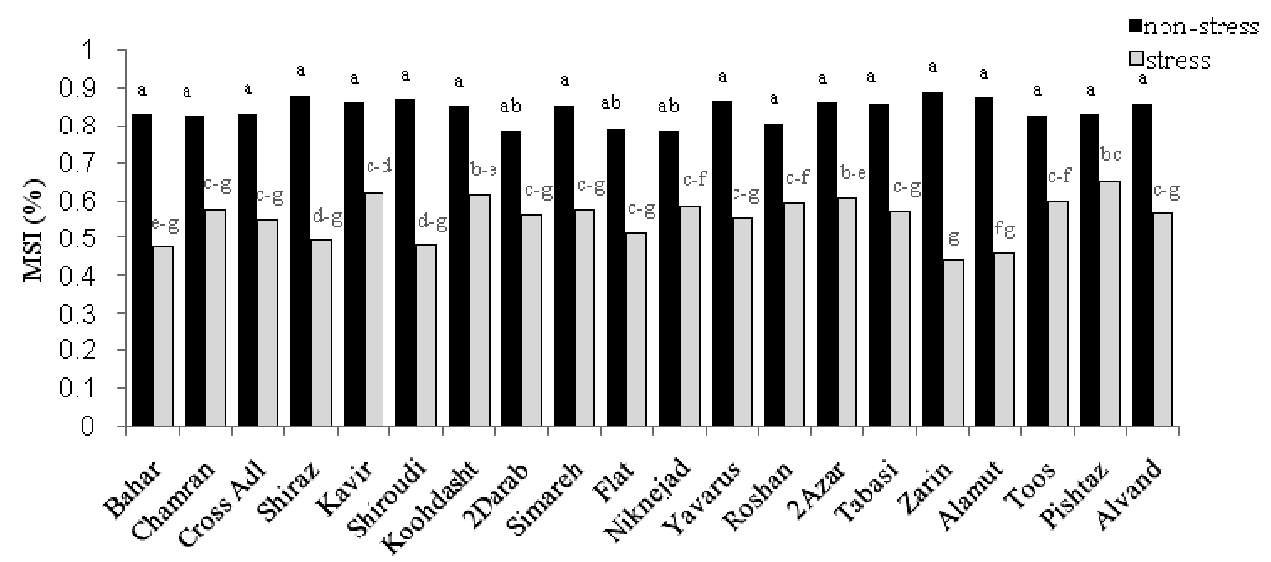

Figure 4. Effect of water stress on membrane stability index (MSI) in wheat genotypes. Different letters indicate significant differences between means of three replicates according to Tukey's test (probability level of \%5) 


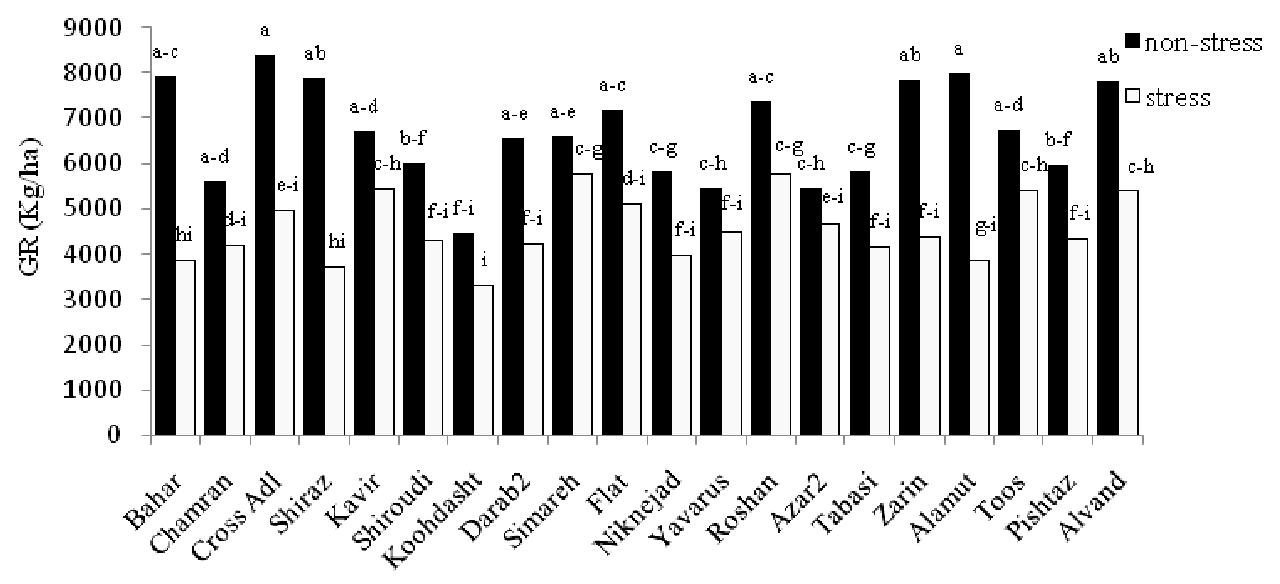

Figure 5. Effect of water stress on grain yield (GR) in wheat genotypes. Different letters indicate significant differences between means of three replicates according to Tukey's test (probability level of \%5)

The results of grain yield $(\mathrm{GY})$ showed that there are significant $(\mathrm{P}<0.05)$ differences among genotypes when grown under drought stress and non-stress conditions (Figure 5). GY significantly $(\mathrm{P}<0.01)$ decreased under stress condition. Drought tolerant genotypes (group 1) on average had the highest GY and lowest in susceptible ones (group 3) While genotypes in group 3 showed intermediate responses (Figure 5). Clearly, the results of GR consistent with other biochemical indicator as measured under water stress condition.

\subsection{Pearson Correlation Analysis}

The result of the correlation analysis under water stress condition showed that enzymatic antioxidants defense had positive and significant correlation with yield stability index (YSI), whereas there were positive and non-significant correlation among non- enzymatic antioxidants and YSI (Table 4). It may be concluded that enzymatic antioxidants are more efficient than non-enzymatic for drought tolerance. There are several reports in the literature that underline the significant relationship between enhanced or constitutive enzymatic antioxidants activity and increased tolerance to drought stress (Zlatev et al., 2006; Abedi \& Pakniyat, 2010; Ahmadi et al., 2010). SOD activity showed positive and significant $(\mathrm{P}<0.01)$ correlation with APX, POD and CAT activity. Salekjalali et al. (2012) reported that the induction of SOD activity has been shown to coincide with an increase in APX, POD and CAT activity. The combined action of SOD with CAT and peroxidases (APX and POD) convert the toxic $\mathrm{O}_{2}{ }^{--}$and $\mathrm{H}_{2} \mathrm{O}_{2}$ to water and molecular oxygen $\left(\mathrm{O}_{2}\right)$, thus preventing the cellular damage under water stress condition (Alscher et al., 2002). YSI had negative and significant $(\mathrm{P}<0.01)$ correlation with oxidative stress factors $\left(\mathrm{H}_{2} \mathrm{O}_{2}\right.$ and MDA). Also there were negative and significant correlations among oxidative stress factors and all antioxidants systems with exception of proline (Table 4).

Table 4. Pearson correlations coefficients between studied traits in wheat genotypes under drought stress

\begin{tabular}{lcccccccccc}
\hline Variables & POD & SOD & CAT & APX & Proline & Car & MDA & $\mathrm{H}_{2} \mathrm{O}_{2}$ & MSI & YSI \\
\hline POD & 1 & & & & & & & & & \\
SOD & $0.727^{* *}$ & 1 & & & & & & & \\
CAT & $0.546^{*}$ & $0.578^{* *}$ & 1 & & & & & & \\
APX & $0.790^{* *}$ & $0.722^{* *}$ & $0.724^{* *}$ & 1 & & & & & \\
Proline & $0.025^{\mathrm{NS}}$ & $0.241^{\mathrm{NS}}$ & $0.517^{*}$ & $0.294^{\mathrm{NS}}$ & 1 & & & & \\
Car & $0.328^{\mathrm{NS}}$ & $0.543^{*}$ & $0.38^{\mathrm{NS}}$ & $0.528^{*}$ & $0.354^{\mathrm{NS}}$ & 1 & & & \\
MDA & $-0.767^{* *}$ & $-0.712^{* *}$ & $-0.569^{* *}$ & $-0.697^{* *}$ & $-0.425^{\mathrm{NS}}$ & $-0.42^{\mathrm{NS}}$ & 1 & & \\
$\mathrm{H}_{2} \mathrm{O}_{2}$ & $-0.817^{* *}$ & $-0.800^{* *}$ & $-0.596^{* *}$ & $-0.794^{* *}$ & $-0.421^{\mathrm{NS}}$ & $-0.550^{*}$ & $0.817^{* *}$ & 1 & \\
$\mathrm{MSI}$ & $0.818^{* *}$ & $0.793^{* *}$ & $0.543^{*}$ & $0.703^{* *}$ & $0.334^{\mathrm{NS}}$ & $0.501^{*}$ & $-0.840^{* *}$ & $-0.948^{* *}$ & 1 & \\
YSI & $0.609^{* *}$ & $0.580^{* *}$ & $0.593^{* *}$ & $0.499^{*}$ & $0.297^{\mathrm{NS}}$ & $0.324^{\mathrm{NS}}$ & $-0.618^{* *}$ & $-0.760^{* *}$ & $0.746^{* *}$ & 1 \\
\hline
\end{tabular}

* and **: Significant at the 0.05 and 0.01 probability levels, respectively. NS $=$ Non-significant. 
Our result clearly indicated efficient role of antioxidant defense machinery in protection of cell systems against oxidative damage. The enzymatic antioxidants had a higher correlation than non enzymatic with all oxidative stress factors $\left(\mathrm{H}_{2} \mathrm{O}_{2}\right.$, MDA and MSI). It may be reflected more efficient role antioxidant enzymes in compare to non-enzymatic in protects cell systems against oxidative damage. These results are similar to works of Amjad et al. (2011) and Shao et al. (2005). $\mathrm{H}_{2} \mathrm{O}_{2}$ and MSI had the highest correlation with YSI in all the traits. Thus, it can be concluded that $\mathrm{H}_{2} \mathrm{O}_{2}$ and MSI are more effective indicators for screening drought tolerant genotypes in stress condition. Sairam and Sirvastava (2001) had reported that $\mathrm{H}_{2} \mathrm{O}_{2}$ and MSI were good indicators of drought tolerance.

\section{Conclusion}

The results showed that genotypes respond differentially to oxidative damage as a result of variations in their antioxidant defense systems. Under water stress condition, activity of CAT, POD, APX and SOD, proline content, $\mathrm{H}_{2} \mathrm{O}_{2}$ and LPO significantly $(\mathrm{P}<0.01)$ increased while Car and MSI decreased significantly $(\mathrm{P}<0.01)$. Drought tolerant genotypes which had lowest membrane damage (MDI) and $\mathrm{H}_{2} \mathrm{O}_{2}$ content and the highest MSI also showed the highest enzymatic antioxidants activity (CAT, POD, APX and SOD) and non-enzymatic antioxidants (Proline and Car) while drought susceptible genotypes showed the lowest antioxidants defends and MSI, and highest $\mathrm{H}_{2} \mathrm{O}_{2}$ and MDA content. Intermediate drought tolerant genotypes showed a moderately response. Also durum wheat indicated similar behavior of tolerant bread wheat under drought stress. We found that enzymatic antioxidants had play more effective role than non-enzymatic antioxidants in protects cell systems against oxidative damage.

\section{References}

Abedi, T., \& Pakniyat, H. (2010). Antioxidant enzyme changes in response to drought stress in ten cultivars of Oilseed Rape (Brassica napus L.). Czech Journal of Genetics and Plant Breeding, 46(1), 27-34.

Ahmadi, A., Emam, Y., \& Pessarakli, M. (2010). Biochemical changes in maize seedling exposed to drought stress conditions at different nitrogen levels. Journal of Plant Nutrition, 33, 541-556.

Ahmadizadeh, M., Valizadeh, M., Zaefizadeh, M., \& Shahbazi, H. (2011). Antioxidative protection and electrolyte leakage in durum wheat under drought stress condition. Journal of Applied Sciences Research, 7(3), 236-246.

Alexieva, V., Sergiev, I., Mapelli, S., \& Karanov, E. (2001). The effect of drought and ultraviolet radiation on growth and stress markers in pea and wheat. Plant Cell Environment, 24, 1337-1344. http://dx.doi.org/10.1046/j.1365-3040.2001.00778.x

Alscher, R. G., Erturk, N., \& Heatrh, L. S. (2002). Role of superoxide dismutases (SODs) in controlling oxidative stress in plants. Journal of Experimental Botany, 53, 1331-1341. http://dx.doi.org/10.1093/jexbot/53.372.1331

Amjad, H., Noreen, B., Javed, A., \& Nayyer, I. (2011). Differential changes in antioxidants, proteases and lipid peroxidation in flag leaves of wheat genotypes under different levels of water deficit conditions. Plant Physiology and Biochemistry, 49, 178-185. http://dx.doi.org/10.1016/j.plaphy.2010.11.009

Asada, K. (1999). The waterewater cycle in chloroplasts: scavenging of active oxygens and dissipation of excess photons. Annual Review. Plant Physiology and Plant Molecular Biology, 50, 601-639. http://dx.doi.org/10.1146/annurev.arplant.50.1.601

Bates, L. S., Waldern, R. P., \& Teave, I. D. (1973). Rapid determination of free proline for water stress standies. Plant and Soil, 39, 205-107. http://dx.doi.org/10.1007/BF00018060

Beauchamp, C., \& Fridovich, I. (1971). Superoxide dismutases: improved assays and an assay predictable to acrylamide gels. Annals of Clinical Biochemistry, 44, 276-287. http://dx.doi.org/10.1016/0003-2697(71)90370-8

Behnamnia, M., Kalantari, Kh. M., \& Rezanejad, F. (2009). Exogenous application of brassino steroid alleviates drought-induced oxidativestress in Lycopersicon esculentum L. General and Application Plant Physiology, 35, 22-34.

Bouslama, M., \& Schapaugh, W. T. (1984). Stress tolerance in soybean. Part 1: evaluation of three screening techniques for heat and drought tolerance. Crop Science, 24, 933-937. http://dx.doi.org/10.2135/cropsci1984.0011183X002400050026x 
Cadenas, S. E. (1989). Biochemistry of oxygen toxicity. Annual Review. Biochemistry, 58, 79-110. http://dx.doi.org/10.1146/annurev.bi.58.070189.000455

Chance, B., \& Maehly, A. C. (1995). Assay of catalase and peroxidase. New York, Academic Press.

Dhindsa, R. S., Plumb-Dhindsa, P., \& Thorpe, T. A. (1981). Leaf senescence: correlated with increased levels of membrane permeability and lipid peroxidation, and decreased levels of superoxide dismutase and catalase. Journal of Experimental Botany, 32, 93-101. http://dx.doi.org/10.1093/jxb/32.1.93

Dong, B., Liu, M., Shao, H. B., Li, Q., Shi, L., Du, F., \& Zhang, Z. (2008). Investigation on the relationship between leaf water use efficiency and physio-biochemical traits of winter wheat under rained condition. Colloids and Surfaces B: Biointerfaces, 62, 280-287. http://dx.doi.org/10.1016/j.colsurfb.2007.10.023

Foyer, C. H., Descourvieres, P., \& Kunert, K. J. (1994). Protection against oxygen radicals: an important defense mechanism studied in transgenic plants. Plant Cell Environment, 17, 507-523. http://dx.doi.org/10.1111/j.1365-3040.1994.tb00146.x

Geravandi, M., Farshadfar, E., \& Kahrizi, D. (2011) Evaluation of some physiological traits as indicators of drought tolerance in bread wheat genotypes. Russ Journal of Plant Physiology, 58(1), 69-75. http://dx.doi.org/10.1134/S1021443711010067

Golestani, S., \& Assad, M. T. (1998). Evaluation of four screening techniques for drought resistance and their relationship to yield reduction ratio in wheat. Euphytica, 103, 293-299. http://dx.doi.org/10.1023/A:1018307111569

Heath, R. L., \& Packer, L. (1969). Photoperoxidation in isolated chloroplast. I. Kinetics and stoichiometry of fatty acid peroxidation. Archives of Biochemistry and Biophysics, 125, 189-198. http://dx.doi.org/10.1016/0003-9861(68)90654-1

Lichtenthaler, H., \& Wellburn, A. R. (1983). Determination of total carotenoids and chlorophyll a and chlorophyll b leaf extracts in different solvents. Biochemical Society Transactions, 603, 591-592.

Micheal, A. M., \& Oija, T. P. (1987). Principles of agricultural engineering. New Delhi Jain Brothers Publisher. Delhi.

Mittler, R. (2002). Oxidative stress, antioxidants and stress tolerance. Trends in Plant Science, 7, 405-410. http://dx.doi.org/10.1016/S1360-1385(02)02312-9

Mohammadi, R., Haghparast, R., Aghaee-Sarbarze, M., \& Abdollahi, A. V. (2006). An evaluation of drought tolerance in advanced durum wheat genotypes based on physiologic characteristics and other related indices. Iranian Journal of Agricultural Sciences, 37, 561-567.

Nakano, Y., \& Asada, K. (1981). Hydrogen peroxide is scavenged by ascorbate-specific peroxidase in spinach chloroplasts. Plant Cell Physiology, 22, 867-880.

Pireivatloum, J., Qasimov, N., \& Maralian, H. (2010). Effect of soil water stress on yield and proline content of four wheat lines. African Journal of Biotechnology, 9, 036-040.

Ramachandra, A. R., Chaitanya, K. V., Jutur, P. P., \& Sumithra, K. (2004). Differential antioxidative responses to water stress among five mulberry (Morus alba L.) cultivars. Environmental and Experimental Botany, $52,33-42$

Renu, K. C., \& Devarshi, S. (2007). Acclimation to drought stress generates oxidative stress tolerance in drought-resistant than susceptible wheat cultivar under field conditions. Environmental and Experimental Botany, 60, 276-283. http://dx.doi.org/10.1016/j.envexpbot.2006.11.004

Sairam, R. K. (1994). Effect of moisture stress on physiological activities of two contrasting wheat genotypes. Indian Journal of Experimental Biology, 32, 584-593.

Sairam, R. K., \& Srivastava, G. C. (2001). Water stress tolerance of wheat (Triticum aestivum L.): variations in hydrogen peroxide accumulation and antioxidant activity in tolerant and susceptible genotypes. Journal of Agronomy and Crop Science, 186, 63-70. http://dx.doi.org/10.1046/j.1439-037x.2001.00461.x

Salekjalali, M., Haddad, R., \& Jafari, B. (2012). Effects of soil water shortages on the activity of antioxidant enzymes and the contents of chlorophylls and proteins in barley. American-Eurasian Journal of Agricultural \& Environmental Science, 12(1), 57-63.

Sarvajeet, S. G., \& Narendra, T. (2010). Reactive oxygen species and antioxidant machinery in a biotic stress tolerance in crop plants. Annual Review. Plant Physiology and Biochemistry, 3, 1-22. 
Shao, H. B., Liang, Z. S., \& Shao, M. A. (2005). Changes of some anti-oxidative enzymes under soil water deficits among 10 wheat genotypes at maturation stage. Colloids and Surfaces B: Biointerfaces, 45, 7-13. http://dx.doi.org/10.1016/j.colsurfb.2005.06.016

Turkan, I., Bor, M., Ozdemir, F., \& Koca, H. (2005). Differential responses of lipid peroxidation and antioxidants in the leaves of drought-tolerant $P$. acutifolius Gray and drought-sensitive P. vulgaris L. subjected to polyethylene glycol mediated water stress. Plant Science, 168, 223-231. http://dx.doi.org/10.1016/j.plantsci.2004.07.032

Zlatev, Z. S., Lidon, F. C., Ramalho, J. C., \& Yordanov, I. T. (2006). Comparison of resistance to drought of three bean cultivars. Biologia Plantarum, 50(3), 389-394. http://dx.doi.org/10.1007/s10535-006-0054-9 